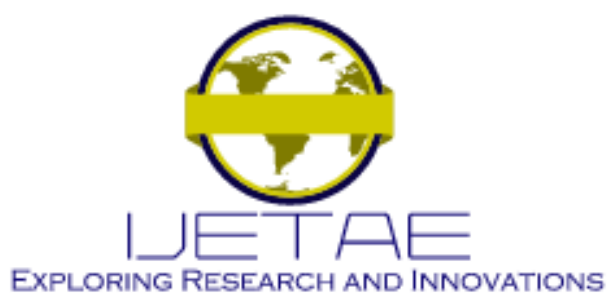

International Journal of Emerging Technology and Advanced Engineering

Website: www.ijetae.com (E-ISSN 2250-2459, Scopus Indexed, ISO 9001:2008 Certified Journal, Volume 11, Issue 12, December 2021)

Manuscript Received: 02 November 2021, Received in Revised form: 01 December 2021, Accepted: 12 December 2021

DOI: 10.46338/ijetae1221_03

\title{
Actionable Decision Support Model Based on Customer Tweet by Analyzing Emotion and Complaint from Bank XYZ
}

\author{
Moh Mahsus ${ }^{1}$, Ditdit Nugeraha Utama ${ }^{2}$ \\ Computer Science Department, BINUS Graduate Program-Master of Computer Science, Bina Nusantara University, Jakarta, \\ Indonesia 11480
}

\begin{abstract}
Bank XYZ has more than 4.539 million mobile banking users in 2020, it's increased $40 \%$ YoY. By the time, bank XYZ focused on digital transformation by launching a super-app platform to encourage customers for moving to the online platform. To support that, social media Twitter is used to interact with the customer. If the tweet does not handle properly, it affects bank services. Multiclass Support vector machine (SVM) is used to extract customer tweets that contain complaints and emotions. The developed model provides an actionable decision that can decide an action to do based on customer tweet classification. The classification and constructed model is applied successfully to 2406 tweets from customers. As the result, by optimizing the soft margin (C) value from 0.1 to 1 by 0.01 stepping, the SVM classifier reaches the best accuracy of $77.36 \%$ on emotion with data validation for $C$ value 0.62 , and 72.54 on the complaint with cross-fold validation for $\mathrm{C}$ value 0.94 . And actionable DSM provides action to $0.54 \%$ direct message and $99.46 \%$ reply tweet. Modification of SVM by optimizing the soft margin performs well with the dataset. Action can be suggested with rule-based actionable DSM to address customer complaints.
\end{abstract}

Keywords - DSM, emotion, multiclass support vector machines, social media, soft margin.

\section{INTRODUCTION}

Based on corporate report release bank XYZ, there has been an increase in mobile banking users by $40 \%$ (YoY), reaching 4.539 million by the end of 2020 [1]. In 2021, bank XYZ will focus on digital transformation by launching a super-app platform to encourage customers for moving to the online platform (branchless banking). However, with a massive shifting to online platforms (branchless banking). To support the online platform, bank $\mathrm{XYZ}$ decides to use social media Twitter to interact with the customer.

Every tweet must be a response as soon as possible from a customer service agent. Every tweet has different handling based on a complaint or not based on customer service agent judgment.
If it is a complaint, the agent must follow up on the customer and related parties to resolve the complaint and update the knowledge based on it. As for not complaining, most of the answers already exist in the knowledge based. This condition is not ideal because every agent do their judgment based on their experience or mood to classify complaints from customers. As a financial services company, maintaining its reputation and providing services is a top priority. This is indicated by winning "Banking Service Excellence Awards 2020" from Infobank Magazine and Marketing Research Indonesia (MRI) [2].

On the other hand, the social media is media that is not based on a specific structure determined by a social media platform, but everyone can determine each other by sharing information/messages [3]. However, the communication that occurs on social media/written communication is indirect, where the expression of the complaints of the customers involved can only be known through written tweets [4] [5]. To see one's emotions on social media, it is necessary to analyze and model the tweet that someone wrote [6]. Determination of the emotional status on which is written is divided into six types of emotions that are angry, afraid, happy, sad, and surprised. Research on the classification of social media emotions can provide benefits for finding information about a person's attitudes and emotions for a product, brand, film, company strategy, government policy, and others [7].

social media is a suitable medium for most researchers to perform analysis on [8] [9], including emotion and complain. By exploring it, we are also able to gain information that is valuable to support decision-making that can bring benefits to individuals and companies [10]. From that situation, we can develop a multiclass support vector machine to handle the complaint and add emotion to customer tweets classification, and actionable decision support models to generate several actions to handle that customer's tweet. 


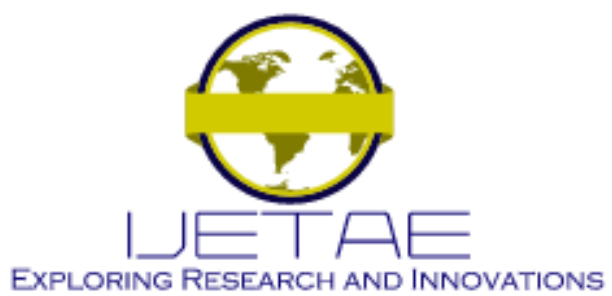

International Journal of Emerging Technology and Advanced Engineering

Website: www.ijetae.com (E-ISSN 2250-2459, Scopus Indexed, ISO 9001:2008 Certified Journal, Volume 11, Issue 12, December 2021)

\section{LITERATURE REVIEW}

In 2002, the research conducted to compare the Multiclass Support Vector Machine method with the One Against All (OAA) and One Against One (OAO) method. They are the ones who initiated LibSVM which is one of the popular libraries until now based on Java to perform data classification processing based on SVM and its kernel. In this experiment, it was found that the OAO method was more appropriate and more practical. So that in LibSVM the OAO method is implemented to perform multiclass classification [11].

Then in 2011, the Gradient Boosted Decision Trees (GBDT) algorithm implemented to classify the tendency of Twitter users into three classes, namely whether users are political, ethnic, or business-oriented. This study uses several selection features, namely profile features (identifying users), tweeting behavior (how users write), linguistic content (what content users write), and social networks (to whom users write tweets). To identify the pattern of users who tend to discuss politics, a dataset of users who explicitly state their support for the democratic or republican party is taken as many as 10388 users. Meanwhile, to identify the pattern of users who tend to discuss ethnicity, a dataset of users who stated themselves explicitly of African American blood as a positive set and other ethnicities as a negative set was taken, and each numbered 3000 users. Finally, to identify the pattern of users who tend to have a business orientation, a dataset of 5000 users who follow a Starbucks account is taken as a positive set and those who do not follow as many as 5000 users as a negative set. The accuracy obtained is about $76 \%$ [12].

Furthermore, in 2015, in one study, the NBC method operated to classify a person's emotional expression based on words or sentence expressions written by Twitter users. The classification of emotions consists of 6 categories, namely joy, sadness, fear, anger, surprise, and disgust. With this method, sentences will be represented as a variable and trained with a dataset so that the category/class with the highest probability is obtained. This study contained 1366 unique words with 423 training data and 105 test data. The results of this study have obtained an accuracy of $83.10 \%$ [13].

In 2018 , there was a study that analyzed information on social media using text classification techniques, including Naïve Bayes, SVM, and Decision Tree. From this study, it was found that SVM produces the highest accuracy compared to the other three methods [10].
Then in 2020, the study of sentiment analysis on tweets using multiclass SVM, using the OAA method which resulted in an accuracy of $80.59 \%$ conducted. The data used is tweet data, which is classified into 3 classes, namely positive, negative, and neutral [5].

In 2019 and 2020, social media study focusing on extracting highlighted information and data to analyze and construct a smart decision support model (smart DSM) to purpose solutions to waste and waste management in Indonesia already held by using analysis, fuzzy logic, and mathematical approach to construct the model. with DSM that constructed based on Twitter users' behavior, the result for this model is 56.90 out of 100,00 at 2019 and 56.02 out of 100,00 at 2020 that's mean quality of waste management in Indonesia should be upgraded extremely [8] [14]

Based on the results of the research that has been done, the authors propose to make a classification model for types of complaints using multiclass SVM to classify 7 types of emotions and 2 types of complaints so that they can generalize the classification process. Then make a submodel of determining the type of response based on the type of complaint to help make decisions about who and what to do by customer service agents.

\section{THEORIES AND METHODS}

\section{A. Support Vector Machine}

Support Vector Machines (SVM) is a supervised learning method for data classification in data mining. SVM works by building a hyperplane with the maximum distance by using a support vector (SV) in classifying data. SVs are all data vectors that are closest to the hyperplane. SVM works very well for binary classification problems, namely classifications, that have only two classes. for nonbinary classifications cases such as angry, afraid, happy, sad, and surprised classification a Multiclass Support Vector Machine (MSVM) approach is needed to handle that [15] [5].

\section{B. Multiclass Support Vector Machine.}

There are two approaches to implementing the Multiclass Support Vector Machine method by combining several binary SVMs namely One Against All (OAA) and One Against One (OAO). The OAA approach solves Multiclass problems or more than two classes ( $\mathrm{N}$ classes) with $\mathrm{N}$ decision boundaries. The resulting decision boundary is the result of the hyperplane of each I class with the rest of the class. 


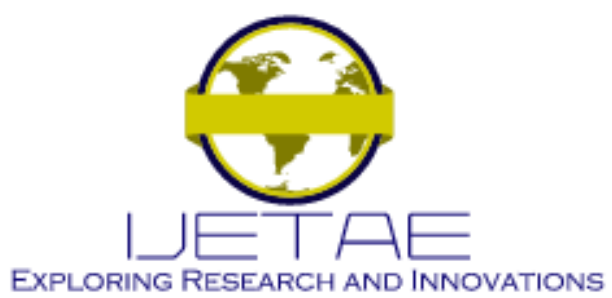

International Journal of Emerging Technology and Advanced Engineering

Website: www.ijetae.com (E-ISSN 2250-2459, Scopus Indexed, ISO 9001:2008 Certified Journal, Volume 11, Issue 12, December 2021)

The OAO approach solves Multiclass problems or more than two classes ( $\mathrm{N}$ classes) with $\mathrm{N}(\mathrm{N}-1) / 2$ decision boundaries. The decision boundary is the hyperplane of each class with every other class. Experiments on large problems show that the one-against-one method may be more suitable for practical use [11].

\section{Decision Support Model (DSM).}

The decision support model (DSM) is a model created to produce a decision support system (DSS) that supports creating objective decisions in the right way. There are two main keys to creating DSS, it must be done in the right way, that's mean it's verified, structured, accountable, logical, and rational. Then, the decision must be objective. Some decisions may be wrong or not suitable in some cases, but that decision must be accountable [16].

\section{RESEARCH Methodology}

\section{A. Research Framework.}

From the research framework in Figure 1, there are some problems in social media customer handling from customer care groups. These problems exist because the bank didn't have a standard classification for customer complain that imply improper customer handling that caused by missed classify customer complaints. On the other hand, the bank already has customer service agents leveling from junior, senior, and supervisor based on their experience to handle customer's complaints.

This study produces a method to classify complaints and emotions from a customer based on their tweet to bank XYZ official Twitter account. Then generate a model to generate several actions that match with classification criteria.

\section{B. Research Stages.}

There are four stages of this research (Figure 2), from literature studying until model evaluation. First, a literature study is performed to obtain the knowledge for the researcher. Once the knowledge is obtained, the next step is to interview the employee of bank XYZ to understand the problem, current condition, and other data that are relevant to this research.
In this stage, the researcher defines there are seven types of emotion consist of "Neutral", "Happy", "Sad", "Angry", "Fear", "Shock", dan "Disgusting" that explained by Kamus Besar Bahasa Indonesia (KBBI). KBBI is The Great Dictionary of the Indonesian Language of the Language Center is the official dictionary of the Indonesian language. Produced by the Language Center of the Indonesian Ministry of Education and Culture. Followed by tagging that word that describes emotion as shown in Table 1. There are two types of a complaint or called "Case" consisting of "Complain" and "Information" that describe customer condition when contacting the bank based on their information as shown in Table 2. From the interview, we manage to know there are 3 types of customer service agents consist of junior, senior, and supervisor with different privileges to handle customers as shown in Table 3 with junior being the lowest privilege and supervisor being the higher one.

TABLE 1

TYPES OF EMOTION

\begin{tabular}{|c|c|c|}
\hline Emotion & KBBI Definition & Tag \\
\hline Happy & $\begin{array}{l}\text { Happy Satisfied and relieved, } \\
\text { without feeling difficult and } \\
\text { disappointed, etc. }\end{array}$ & $\begin{array}{l}\text { Happy, Excited, Pleased, } \\
\text { Cheerful, Satisfied, love, } \\
\text { Amused, Adore. }\end{array}$ \\
\hline Sad & Feeling very sad inside; sad & $\begin{array}{l}\text { Sad, Regret, Hopeless, } \\
\text { Depressed, Gloomy, } \\
\text { Emotion, Sorrow, Wrath. }\end{array}$ \\
\hline Angry & $\begin{array}{l}\text { Very displeased (because of } \\
\text { being insulted, mistreated, } \\
\text { and so on); angry; furious. }\end{array}$ & $\begin{array}{l}\text { Angry, Annoyed, Wrath, } \\
\text { Geek, Spite, Hate, } \\
\text { Suspicious, Late, Bored, } \\
\text { Jealous, Irritated, } \\
\text { Disappointed. }\end{array}$ \\
\hline Fear & $\begin{array}{l}\text { Feel trepidation (horrified) to } \\
\text { face something that is } \\
\text { considered to be a disaster }\end{array}$ & $\begin{array}{l}\text { afraid, anxious, horrified, } \\
\text { nervous, doubtful, afraid, } \\
\text { trepidation, worried }\end{array}$ \\
\hline Shock & $\begin{array}{l}\text { Become stiff (about the } \\
\text { veins, limbs) due to shock } \\
\text { and so on; startled }\end{array}$ & $\begin{array}{l}\text { Surprised, Shock, Sigh, } \\
\text { Wonder }\end{array}$ \\
\hline Disgusting & $\begin{array}{l}\text { Don't like to see (nausea and } \\
\text { so on) because it's dirty, vile, } \\
\text { and so on }\end{array}$ & $\begin{array}{l}\text { Disgusting, Impure, } \\
\text { Uncomfortable, Nausea, } \\
\text { Antipathy }\end{array}$ \\
\hline Neutral & Can't identify the emotions & N/A \\
\hline
\end{tabular}




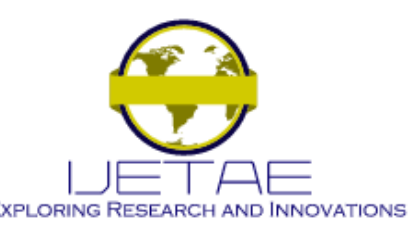

\section{International Journal of Emerging Technology and Advanced Engineering} Website: www.ijetae.com (ISSN 2250-2459, ISO 9001:2008 Certified Journal, Volume, Issue No., Current Month 2020)

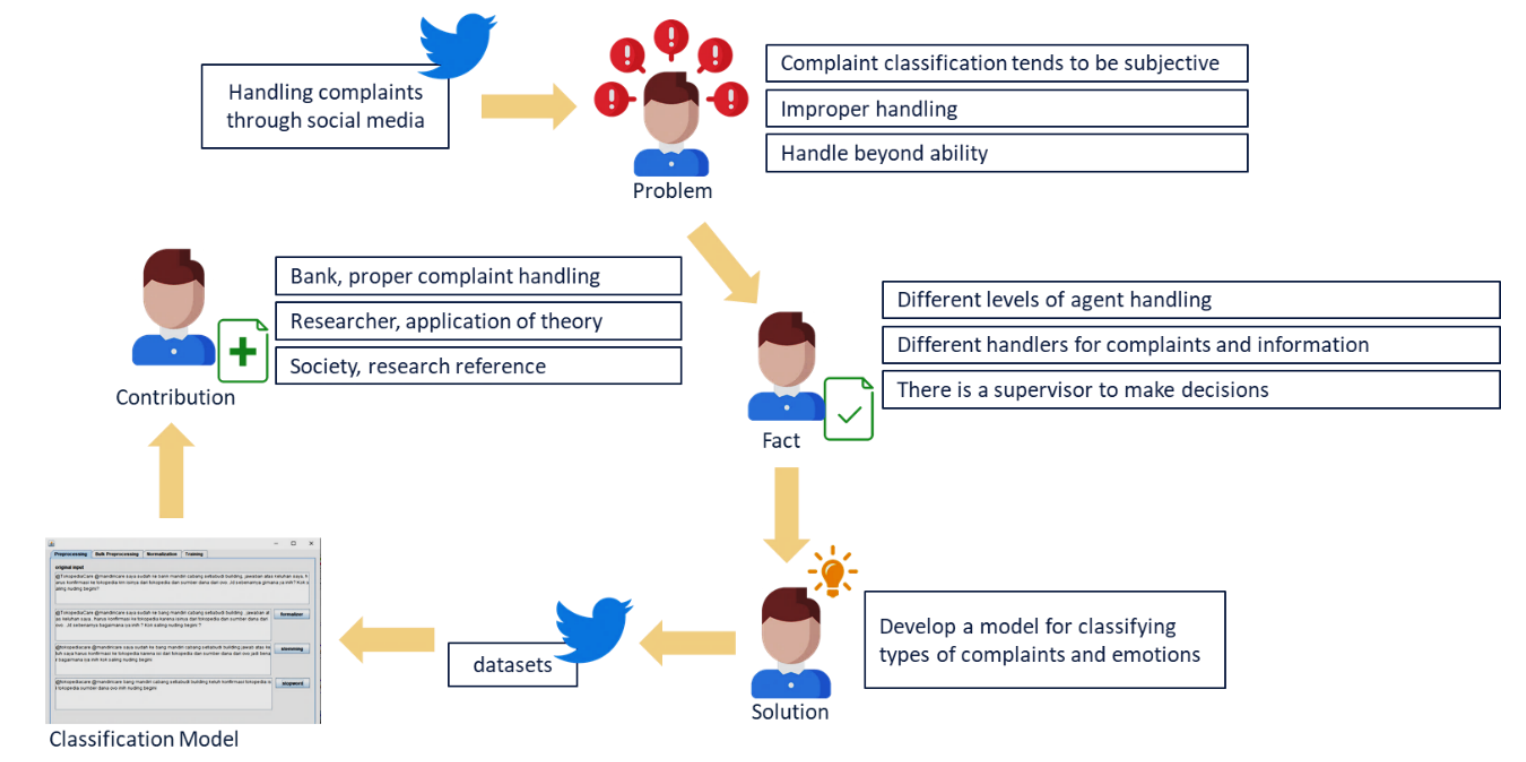

Figure 1 - Research Framework

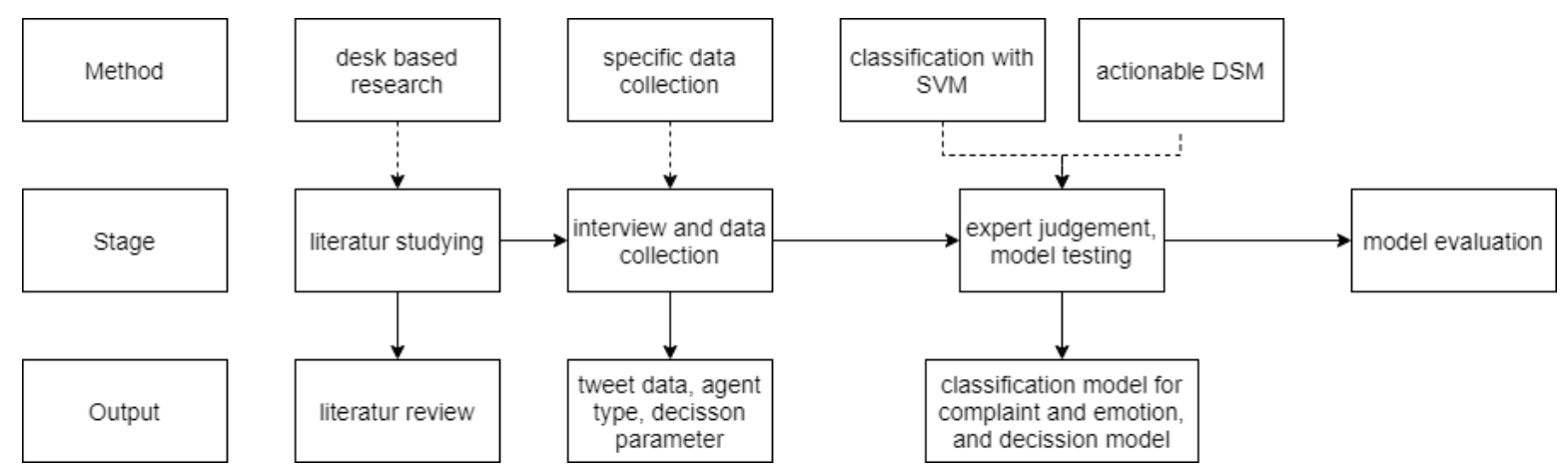

Figure 2 - Research stages

TABLE 2

TYPES OF COMPLAINTS

\begin{tabular}{|c|l|}
\hline \multicolumn{1}{|c|}{ Case } & \multicolumn{1}{|c|}{ Description } \\
\hline Complaint & $\begin{array}{l}\text { Condition in which a customer expresses a } \\
\text { complaint about a banking service }\end{array}$ \\
\hline Information & $\begin{array}{l}\text { Condition in which a customer } \\
\text { applies/requests/submission of information on a } \\
\text { banking service }\end{array}$ \\
\hline
\end{tabular}

TABLE 3

TYPES OF AGENTS

\begin{tabular}{|l|l|}
\hline \multicolumn{1}{|c|}{ Agent } & \multicolumn{1}{c|}{ Authority } \\
\hline Junior & handle information case, except angry emotion \\
\hline Senior & $\begin{array}{l}\text { handle information case with angry emotions, } \\
\text { complaints case with happy, sad, scared, } \\
\text { surprised, disgusted emotions }\end{array}$ \\
\hline Supervisor & Handling complaints case with angry emotions \\
\hline
\end{tabular}




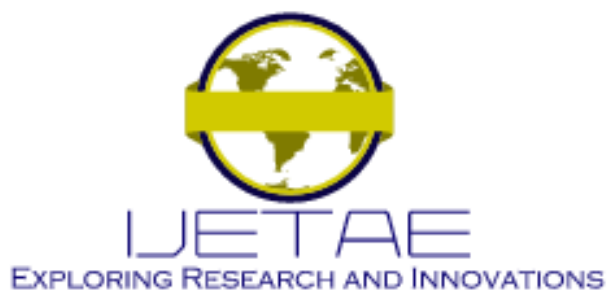

International Journal of Emerging Technology and Advanced Engineering

Website: www.ijetae.com (E-ISSN 2250-2459, Scopus Indexed, ISO 9001:2008 Certified Journal, Volume 11, Issue 12, December 2021)

Then followed with data extraction from the bank XYZ Twitter account in July 2020 with 5660 tweets. Then from the tweet data, only the first tweet that mentions the @ mandiricare account is obtained, and 2406 data is obtained. The data is divided into training data, validation data, and testing data as many as 1450, 479, and 477 data. The data extraction process uses the Twint engine to get all Twitter based on the Twitter user id. For the labeling process, it was carried out manually by four independent people for all data and cross-checking the validity of the labels given by the four people. The most similarities were taken as the correct labels as shown in Table 4.

TABLE 4

CUSTOMER TWEET AFTER LABELING

\begin{tabular}{|l|}
\hline \multicolumn{1}{|c|}{ Customer Tweet } \\
\hline $\begin{array}{l}\text { 1279626186625146885;Sedih;Komplain;Sudah mbak almaa tetep } \\
\text { gabisa:((() }\end{array}$ \\
\hline $\begin{array}{l}\text { 1279629848483266560;Netral;Informasi;Haloo sudah sayaa kirim } \\
\text { email terimakasih }\end{array}$ \\
\hline $\begin{array}{l}\text { 1283960624087592961;Marah;Komplain;Gimana kak.. koq rusak } \\
\text { lagi... Tiap bulan bisa bbrp x rusak }\end{array}$ \\
\hline
\end{tabular}

Once data extraction has been done, the next step is preprocessing to normalize using the $\mathrm{TF}$ normalization equation (1).

$$
T F(t, D)=\frac{f(t, D)}{\text { maxFreq }(D)}
$$

\section{PROPOSED APPROACH}

\section{A. Classification.}

In this paper, we proposed multiclass SVM with the linear kernel using OAO that is more suitable and practical to use for emotion classification that consists of seven classes [11]. For emotion, it's an only binary class then we will use SVM with linear kernel. SVM optimization is done to find the best hyperplane. The best hyperplane is the one that has the most significant margin. The largest margin can be obtained by maximizing the distance between the hyperplane and its closest point. The $\mathrm{C}$ parameter is added in SVM development using the dual form to limit the $\alpha$ value for linearly non-separable data. This is done so that a hyperplane can be tolerated when there is data located in the shady hyperplane area.

\section{B. Model Architecture and Parameters.}

In the following architecture that can be seen in figure 3, the sequencing process in detail and shows the relationship between one process to others. The process starts with data extraction that collects data from Twitter to create raw datasets using the Twint engine and filtering only the first tweet that mentions the official Twitter account bank XYZ and manually labeled. Then deletes the HTML tags, URL, Carriage Return "'r", Line Feed "In", and quotes "“" which still exists in some data. Then all characters are changed to lowercase to match the index. Then formalizing, stemming, and deleting stop words will be carried out using the InaNLP engine. After preprocessing, we got 2406 data that were divided into training data, validation data, and testing data as many as 1450, 479, and 477 records. The data will be classified using SVM to find the best hyperplane using LIBSVM for Java.

From the first classification, we get the class of "Case" consisting of "Complain" and "Information". From this result, we conduct multi-class classification to determine emotion labels such as "Neutral", "Happy", "Sad", "Angry", "Fear", "Shock", and "Disgusting". The final result from classification as shown in figure 4 will be processed to actionable DSM as shown on Table 5 to decide who and what agent must do based on class "Case" and class "Emotion".

TABLE 5

RULE BASED DSM

\begin{tabular}{|l|l|}
\hline Rule 1 & $\begin{array}{l}\text { if (Case = information and Emotion = angry) then } \\
\text { direct message handle with senior agent }\end{array}$ \\
\hline Rule 2 & $\begin{array}{l}\text { if (Case = information and Emotion <> angry) then } \\
\text { reply tweet handle with junior agent }\end{array}$ \\
\hline Rule 3 & $\begin{array}{l}\text { if (Case = complaint and Emotion in (happy or sad or } \\
\text { neutral or disgusting)) then reply tweet handle with } \\
\text { senior agent }\end{array}$ \\
\hline Rule 4 & $\begin{array}{l}\text { if (Case = complaint and Emotion <> angry) then } \\
\text { reply tweet handle with senior agent }\end{array}$ \\
\hline Rule 5 & $\begin{array}{l}\text { if (Case = complaint and Emotion in (fear or shock or } \\
\text { angry) and word occurrence > 30\%) then voice call } \\
\text { handle with supervisor agent }\end{array}$ \\
\hline
\end{tabular}

\section{Classification Accuracy and Model Result}

The evaluation to be carried out using the accuracy parameter is based on the output using the confusion matrix. In the confusion matrix itself, to determine the accuracy of the test the following equation 8 is used. 


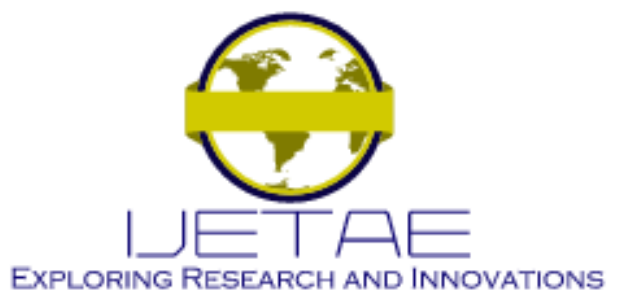

International Journal of Emerging Technology and Advanced Engineering

Website: www.ijetae.com (E-ISSN 2250-2459, Scopus Indexed, ISO 9001:2008 Certified Journal, Volume 11, Issue 12, December 2021)

$$
\text { accuracy }=\frac{T P+T N}{T P+F P+F N+T N}
$$

Which TP is the amount of positive data classified correctly, TN is the amount of negative data classified correctly, FP is the amount of positive data but classified incorrectly, and FN is the amount of negative data but classified incorrectly by the system as shown in the confusion matrix in Table 5.

To validate the result, we are using cross-fold validation 10 times and validation data to get the best model to classify testing data. The best model in the cross-fold validation process and validation data is used to classify the testing data and produce the following data.

Based on data in Table 6, the training model validation method using validation data is slightly more accurate rather than cross-validation in emotion classification. But researchers found opposite conditions in complaint classification. Using actionable decisions in Figure 4, we get the result as shown in Table 7 .
TABLE 6

CONFUSION MATRIX

\begin{tabular}{|l|l|l|}
\hline \multirow{2}{*}{ Prediction } & \multicolumn{2}{|c|}{ Actual } \\
\cline { 2 - 3 } & \multicolumn{1}{|c|}{ Positive } & \multicolumn{1}{c|}{ Negative } \\
\hline Positive & True Positives(TP) & False Positives(FP) \\
\hline Negative & False Negatives(FN) & $\begin{array}{l}\text { True } \\
\text { Negatives(TN) }\end{array}$ \\
\hline
\end{tabular}

TABLE 7

TABLE OF CLASSIFICATION RESULTS BASED ON THE MODEL THAT HAS BEEN BUILT

\begin{tabular}{|l|l|r|r|r|c|}
\hline Class & \multicolumn{1}{|c|}{ Validation } & $\mathrm{C}$ & $\begin{array}{c}\text { Total } \\
\text { correc } \\
t\end{array}$ & $\begin{array}{c}\text { Total } \\
\text { data }\end{array}$ & $\begin{array}{c}\text { Accurac } \\
y\end{array}$ \\
\hline $\begin{array}{l}\text { Emotio } \\
\mathrm{n}\end{array}$ & Cross-fold & 0.6 & 367 & 477 & $76.94 \%$ \\
\hline $\begin{array}{l}\text { Emotio } \\
\mathrm{n}\end{array}$ & $\begin{array}{l}\text { Validation } \\
\text { dataset }\end{array}$ & 0.8 & 369 & 477 & $77.36 \%$ \\
\hline Case & Cross-fold & 0.9 & 346 & 477 & $72.54 \%$ \\
\hline Case & $\begin{array}{l}\text { Validation } \\
\text { dataset }\end{array}$ & $\begin{array}{r}1.0 \\
0\end{array}$ & 344 & 477 & $72.12 \%$ \\
\hline
\end{tabular}
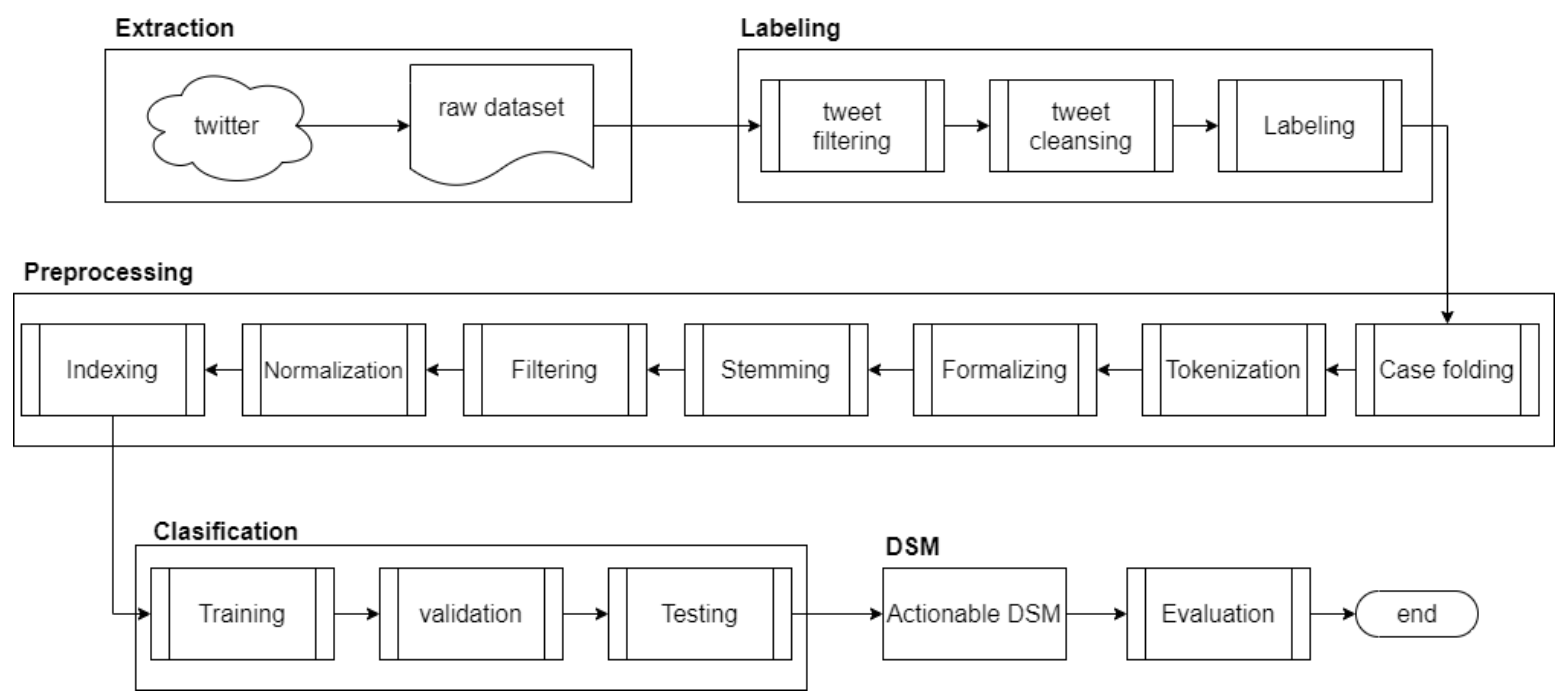

Figure 3 Classification and Model Architecture 


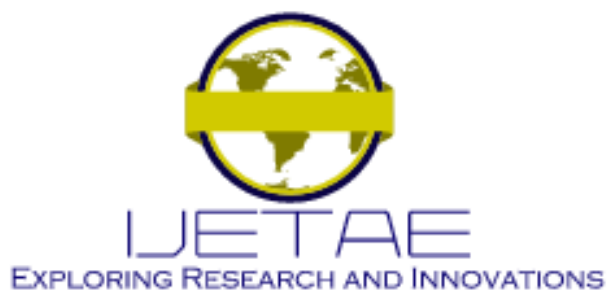

International Journal of Emerging Technology and Advanced Engineering

Website: www.ijetae.com (E-ISSN 2250-2459, Scopus Indexed, ISO 9001:2008 Certified Journal, Volume 11, Issue 12, December 2021)

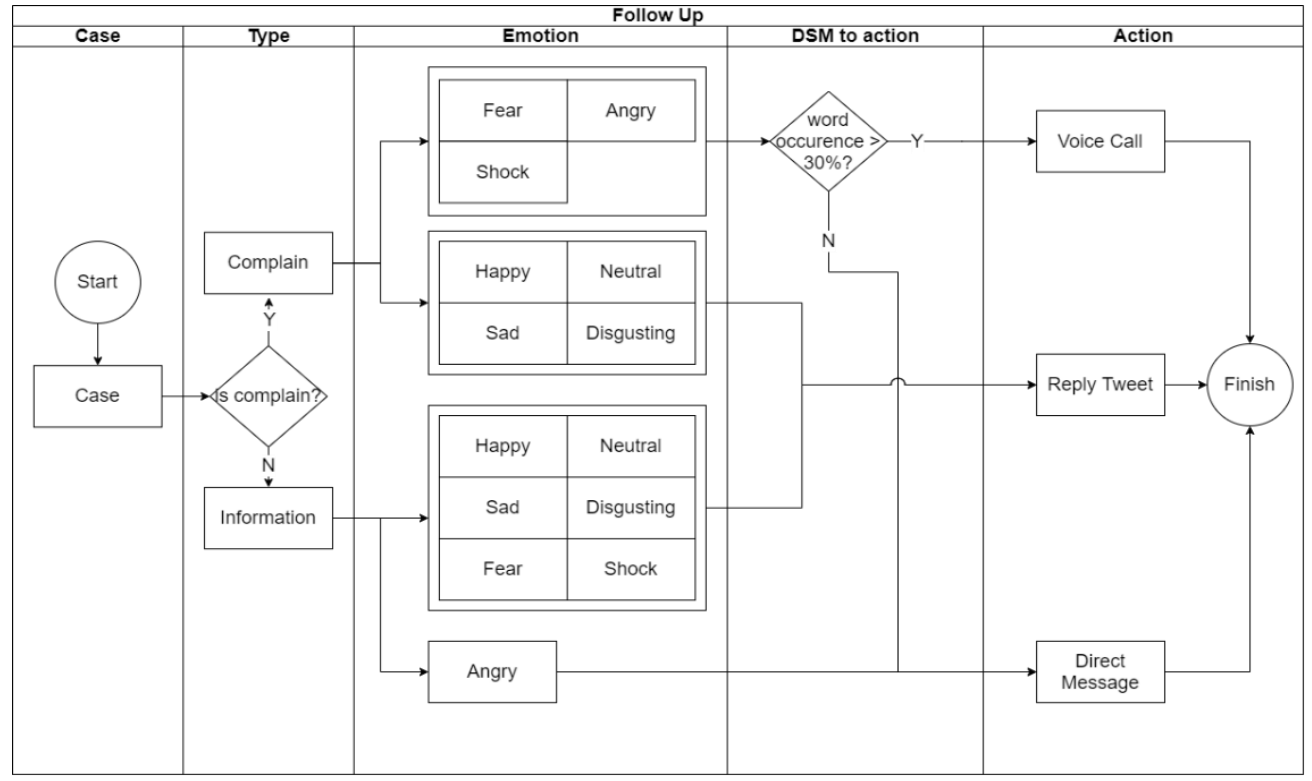

Figure 4 - Actionable DSM

TABLE 8

ACTIONABLE DECISION RESULT

\begin{tabular}{|l|l|r|r|}
\hline \multicolumn{1}{|c|}{ Action } & \multicolumn{1}{|c|}{ Agent } & Information & Complaint \\
\hline Direct Message & Junior & 13 & 0 \\
\hline Reply Tweet & Junior & 0 & 1303 \\
\hline Reply Tweet & Senior & 1090 & 0 \\
\hline Voice Call & Supervisor & 0 & 0 \\
\hline
\end{tabular}

\section{CONCLUSION AND FURTHER WORKS}

Based on the results of tests and analyzes that have been carried out. The model has been tested in a real case, with data from bank XYZ. Modification of SVM by optimizing the soft margin value can update the classification accuracy. The value of $\mathrm{C}$ has an optimal value that varies depending on the classification and type of validation performed. Tweet @mandiricare is dominated by complaints of 54.16, with $29.24 \%$ accompanied by Fear, Shock, and Angry emotions and $24.33 \%$ with neutral emotions. Using actionable DSM, we can barely break the action into a direct message, reply tweet, and voice call to assist customers' needs. By adding the parameter "word occurrence", the researcher reduces entirely for voice call action and moves the action to reply tweet with covering $99.46 \%$ of tweets and only $0.34 \%$ with direct message action.
The work is possibly done in the future study by using a different kernel, or multiclass method to make the classification more optimal.

\section{REFERENCES}

[1] P. B. Mandiri, "Detail Corporate Presentations," 28012021. [Online]. Available: https://bankmandiri.co.id/documents/38265486/38297121/4Q+2020 $+-$

+ Analyst+Meeting+\%28LONG+FORM\%29+\%282\%29.pdf/4dd1e0 83-e917-f347-e1ae-25d9b9d19952.

[2] KeuanganNews.id, "Tahun 2020, Bank Mandiri, BNI, BRI, dan BNI Syariah Masuk dengan Bank Pelayanan Terbaik," 24 July 2020. [Online]. Available: https://keuangannews.id/tahun-2020-bankmandir-bni-bri-dan-bni-syariah-masuk-dengan-bank-pelayananterbaik/.

[3] L. Hjorth and S. Hinton, Understanding social media, SAGE Publications Limited, 2019.

[4] R. C. Balabantaray, M. Mohammad and N. Sharma, "Multi-class twitter emotion classification: A new approach," International Journal of Applied Information Systems, vol. 4(1), pp. 48-53, 2012.

[5] D. N. Fitriana and Y. Sibaroni, "Sentiment Analysis on KAI Twitter Post Using Multiclass Support Vector Machine (SVM)," RESTI journal, vol. 4, no. 5, pp. 846 - 853, 2020.

[6] J. Singh and P. Tripathi, "Sentiment analysis of Twitter data by making use of SVM, Random Forest and Decision Tree algorithm," 2021 10th IEEE International Conference on Communication Systems and Network Technologies (CSNT), pp. 193-198, 2021.

[7] J. Suttles and N. Ide, "Distant supervision for emotion classification with discrete binary values," in In International Conference on Intelligent Text Processing and Computational Linguistics, Springer, Berlin, Heidelberg, 2013. 


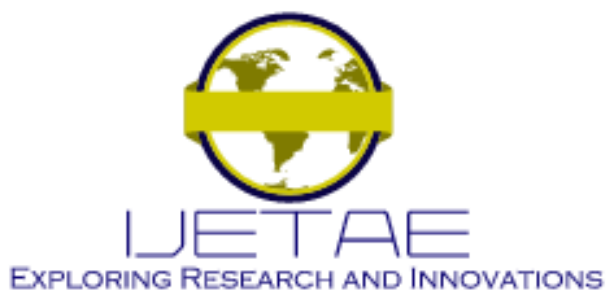

International Journal of Emerging Technology and Advanced Engineering

Website: www.ijetae.com (E-ISSN 2250-2459, Scopus Indexed, ISO 9001:2008 Certified Journal, Volume 11, Issue 12, December 2021)

[8] C. Michael and D. N. Utama, "A Modified DSM Based On Social Media For Treating Waste Management Issue," 2020.

[9] [9] K. Purwandari, R. Rahutomo, J. W. C. Sigalingging, M. A. Kusuma, A. Prasetyo and B. Pardamean, "Twitter-Based Text Classification Using SVM for Weather Information System," 2021.

[10] P. F. Kurnia and S., "Business Intelligence Model to Analyze Social Media Information," Procedia Computer Science, vol. 135, pp. 5-14 2018.

[11] C. W. Hsu and C. J. Lin, "A comparison of methods for multiclass support vector machines," IEEE transactions on Neural Networks, vol. 13, no. 2, pp. 415-425, 2002.

[12] M. Pennacchiotti and A. M. Popescu, "A machine learning approach to twitter user classification," in In Fifth International AAAI Conference on Weblogs and Social Media, 2011.
[13] L. Wikarsa and S. N. Thahir, "A text mining application of emotion classifications of Twitter's users using Naive Bayes method," in In 2015 1st International Conference on Wireless and Telematics (ICWT), 2015.

[14] D. N. Utama, "Media Social based Smart DSM for Strategic Decision Making: Waste Management Case," International Journal of Recent Technology and Engineering (IJRTE), vol. 8, no. 3, pp. 7308-7312, 092019.

[15] S. W. Sidehabi, A. Suyuti, I. I. Areni and A. Nurtanio, "Grading for Ripeness of Passion Fruit Using Multi-Class Support Vector Machine," ICIC International, vol. 9, no. 10, pp. 991-998, 2018.

[16] D. N. Utama, Sistem Penunjang Keputusan: Filosofi, Teori dan Implementasi, Yogyakarta: Garudhawaca, 2017, p. 24. 